\title{
Effect of relative humidity on SOA formation from isoprene/NO photooxidation: enhancement of 2-methylglyceric acid and its corresponding oligoesters under dry conditions
}

\author{
H. Zhang, J. D. Surratt, Y. H. Lin, J. Bapat, and R. M. Kamens \\ Department of Environmental Sciences and Engineering, Gillings School of Global Public Health, the University of North \\ Carolina, Chapel Hill, NC 27599, USA
}

Received: 17 January 2011 - Published in Atmos. Chem. Phys. Discuss.: 14 February 2011

Revised: 29 June 2011 - Accepted: 29 June 2011 - Published: 6 July 2011

\begin{abstract}
The effect of relative humidity (RH) on secondary organic aerosol (SOA) formation from the photooxidation of isoprene under initially high nitric oxide (NO) conditions (i.e., isoprene/NO $\sim 3$ ) was investigated in a dual outdoor smog chamber. Based upon particle volume concentration measurements and the detailed chemical characterization of isoprene SOA using gas chromatography/mass spectrometry (GC/MS) and ultra performance liquid chromatography/electrospray ionization high-resolution quadrupole time-of-flight mass spectrometry (UPLC/ESIHR-Q-TOFMS), enhanced SOA formation was observed under lower RH conditions (15-40\%) compared to higher RH conditions (40-90\%). 2-methylglyceric acid (2-MG) and its corresponding oligoesters, which have been previously shown to form from further oxidation of methacryloylperoxynitrate (MPAN), were enhanced in the particle-phase under lower RH conditions. In addition, an abundant unknown SOA tracer likely derived from the further oxidation of MPAN was detected and enhanced under lower RH conditions. In contrast, the 2-methyltetrols, which are known to mainly form from the reactive uptake of isoprene epoxydiols (IEPOX) under low-NO conditions in the presence of acidified aerosol, did not substantially vary under different $\mathrm{RH}$ conditions; however, isoprene-derived organosulfates were found to be enhanced under high-RH conditions, indicating the likely importance of the aqueous aerosol phase in their formation. Based upon the detailed chemical characterization results, particle-phase organic esterification is tentatively proposed to explain the observed enhancements of isoprene SOA mass under lower RH conditions. Alternative mech-
\end{abstract}

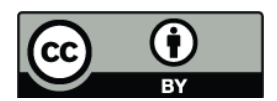

Correspondence to: J. D. Surratt (surratt@unc.edu) anisms explaining the enhancement of 2-MG and its corresponding oligoesters cannot be completely ruled out. This is one of only a few chamber studies that have examined the effect of RH on isoprene SOA formation. In comparison to our recent results obtained from aromatic SOA formation, the effect of RH on isoprene SOA formation is reversed. The results of this study highlight the importance of elucidating the key reactive intermediates that lead to SOA formation, especially since RH likely affects their ability in forming SOA. Furthermore, ignoring the effects of RH may significantly affect the accuracy of both regional and global SOA models.

\section{Introduction}

Atmospheric fine aerosols are known to be associated with adverse public health effects and global climate change (Hallquist et al., 2009). A large portion (40-50\%) of the atmospheric fine aerosol mass is derived from secondary organic aerosol (SOA) materials that form from the oxidation of volatile organic compounds (VOCs) (Turpin and Huntzicker, 1995; Turpin and Lim, 2001; Cabada et al., 2002). Isoprene (2-methyl-1,3-butadiene, $\mathrm{C}_{5} \mathrm{H}_{8}$ ) is the most abundant non-methane volatile organic compound (NMVOC) in the troposphere, with emission rates on the order of 500 $600 \mathrm{Tg} \mathrm{yr}^{-1}$ (Guenther et al., 1995, 2006). Recent studies have shown that SOA formed from isoprene photooxidation can substantially contribute to the global atmospheric aerosol burden (Henze and Seinfeld, 2006; Fu et al., 2008), especially during the summer season (Lewandowski et al., 2008). Globally, isoprene-derived SOA is predicted to be 30 to $50 \%$ of the total SOA (Hoyle et al., 2007; Henze and Seinfeld, 2006).

Published by Copernicus Publications on behalf of the European Geosciences Union. 
Since the first report of isoprene SOA constituents (i.e., 2-methyltetrols) in ambient aerosol samples (Claeys et al., 2004a), numerous laboratory studies have followed in order to understand the formation mechanisms leading to isoprene SOA in the atmosphere (Edney et al., 2005; Dommen et al., 2006; Kroll et al., 2005, 2006; Jaoui et al., 2010; Surratt et al., 2006, 2007b, 2010). Previous work has examined the effects of nitrogen oxides $\left(\mathrm{NO}_{\mathrm{x}}=\mathrm{NO}+\mathrm{NO}_{2}\right)$ (Kroll et al., 2006; Paulot et al., 2009; Surratt et al., 2006, 2010) and aerosol acidity (Edney et al., 2005; Surratt et al., 2007b, 2010; Jaoui et al., 2010; Szmigielski et al., 2010) on isoprene SOA formation. 2-methyltetrols and 2-methylglyceric acid (2-MG), which now serve as molecular tracers for isoprene SOA formation used in source apportionment of ambient aerosol (Kleindienst et al., 2007), were detected and confirmed to be major SOA constituents in both field and chamber studies under low- and high- $\mathrm{NO}_{\mathrm{x}}$ conditions, respectively (Claeys et al., 2004b; Edney et al., 2005; Surratt et al., 2006, 2010). The SOA formation mechanism under low$\mathrm{NO}_{\mathrm{x}}$ conditions has been proposed by Paulot et al. (2009) and Surratt et al. (2010); specifically, the reactive uptake of isoprene epoxydiols (IEPOX) onto acidic aerosols is key to SOA formation from isoprene. Under high- $\mathrm{NO}_{\mathrm{x}}$ conditions it has been shown that further oxidation of methacryloylperoxynitrate (MPAN) leads to SOA formation from isoprene and is enhanced under increasing initial $\mathrm{NO}_{2} / \mathrm{NO}$ ratios (Surratt et al., 2010; Chan et al., 2010). However, the key intermediate(s) from MPAN oxidation that lead to SOA formation have remained elusive, especially since the MPAN-derived oxidation product that was previously proposed by Surratt et al. (2010) is not consistent with the chemical ionization mass spectrometry (CIMS) gas-phase data in Chan et al. (2010).

Enhancements of SOA mass from isoprene oxidation have been shown to correlate with increasing aerosol acidity (Edney et al., 2005; Surratt et al., 2007b, 2010; Jaoui et al., 2010; Szmgielski et al., 2010). In addition to 2-methyltetrol formations, these enhancements have been shown to result (in part) due to the formation of isoprene-derived organosulfates (Surratt et al., 2007a, 2008; Gómez-González et al., 2008). Of these organosulfates, the IEPOX-derived organosulfate has recently been shown to be one of the most abundant single compounds in high-altitude aerosol (Froyd et al., 2010).

In addition to $\mathrm{NO}_{\mathrm{x}}$ level and aerosol acidity, aqueousphase chemistry may also play a role in isoprene SOA formation (Carlton et al., 2007; Altieri et al., 2008). Isoprene oxidation contributes approximately 50 and $80 \%$ towards the global budgets of glyoxal and methylglyoxal, respectively (Fu et al., 2008). Owing to their high water solublities, their uptake by aqueous-phase aerosols, followed by oxidation and oligomerization could be a significant SOA source (Volkamer et al., 2009; Carlton et al., 2009; Ervens and Volkamer, 2010). Recent studies of aromatic systems suggest that glyoxal and methylglyoxal oligomers could contribute significantly to the aromatic SOA formation under humid conditions; aromatic SOA yields can be a factor of 2 to 5 higher than that under dry conditions (Kamens et al., 2011; Zhou et al., 2011). Higher isoprene-derived SOA yields under humid conditions were proposed in recent modeling studies (Couvidat and Seigneur, 2010); however, the authors indicated experimental confirmation was needed. Whether or not the particle-phase aqueous chemistry of glyoxal and methylglyoxal is the only pathway that makes a difference under varied $\mathrm{RH}$ conditions is still unknown.

Although the roles of $\mathrm{NO}_{\mathrm{x}}$, aerosol acidity, and aqueousphase chemistry on isoprene SOA formation have been previously examined, most of the prior chamber studies have been conducted under dry conditions (RH $<30 \%$ ) (Edney et al., 2005; Kroll et al., 2006; Surratt et al., 2006, 2007b, 2010). Besides the study of Dommen et al. (2006), no other direct laboratory comparisons between low- and high-RH conditions on isoprene SOA formation currently exist in the literature. The primary glyoxal and methylglyoxal yields of isoprene photooxidation are between $1 \%$ and $3 \%$ (Orlando, 2010); which are much lower than those from the aromatic systems (Calvert et al., 2002). Dommen et al., (2006) observed that the volatility of isoprene SOA was much lower at lower RH compared to higher RH conditions, which suggests that another chemical mechanism is operating in addition to the aqueous-phase glyoxal and methylglyoxal SOA formation. Therefore, in this study we explored the effect of lowand high-RH conditions on isoprene SOA formation by using identical initial isoprene and NO concentrations, as well as similar environmental conditions, in a large dual outdoor smog chamber. Higher SOA formation was observed under dry conditions, suggesting a low-RH favored pathway was dominating the formation of isoprene SOA in the presence of initially high-NO conditions.

\section{Experimental section}

\subsection{Chamber experiment}

Two sets of humid-dry experiments were conducted at the University of North Carolina $274 \mathrm{~m}^{3}$ dual outdoor smog chamber in Pittsboro, NC under clear natural sunlight. The experimental facility has been described in previous studies (Lee et al., 2004; Leungsakul et al., 2005; Kamens et al., 2011). The smog chamber is divided by a Teflon film curtain into two separated sides: a $136 \mathrm{~m}^{3}$ side referred as "North (N)" and a $138 \mathrm{~m}^{3}$ side referred as "South (S)." Both sides of the chamber were vented with rural North Carolina background air for at least $6 \mathrm{~h}$ before each experiment. A subsequent drying process was performed with a $250 \mathrm{~L} \mathrm{~min}^{-1}$ Aadco clean air generator at a flow rate of $6 \mathrm{~m}^{3} \mathrm{~h}^{-1}$ to each side of the chamber. Three days of drying was performed in one chamber to obtain low-RH conditions; a high-RH chamber was obtained by only using the clean air generator for one to two hours. The background aerosol mass concentrations were less than $2 \mu \mathrm{g} \mathrm{m}^{-3}$ in the humid experiments and less 
than $0.3 \mu \mathrm{g} \mathrm{m}^{-3}$ in the dry experiments. $0.4 \mathrm{M}$ ammonium sulfate was injected as seed aerosol using a nebulizer before each experiment started. After the ammonium sulfate aerosol volume concentration stabilized, $\mathrm{NO}$ was injected into the chamber from a high-pressure gas cylinder. In all experiments presented here, the initial isoprene/NO ratios were $\sim 3$, resulting in similar initial oxidative conditions (i.e., $\mathrm{RO}_{2}+$ NO dominates). Pure liquid isoprene (99\%, Aldrich, Milwaukee, WI) was then vaporized and heated in a U-tube and flushed into the chamber with a $\mathrm{N}_{2}$ flow. The measurements of ozone $\left(\mathrm{O}_{3}\right), \mathrm{NO}_{\mathrm{x}}$, and hydrocarbons from the chamber are described in detail elsewhere (Hu et al., 2007; Kamens et al., 2011).

Particle size distributions and the volume concentrations are measured using two different scanning mobility particle sizers (SMPS) (DMA TSI 3081 and TSI 3080) with a condensation nuclei counter for each SMPS (CPC, TSI 3022A and TSI 3025A, respectively). SMPS measurements were not performed with dried aerosols. The reason for not drying aerosols before going through our SMPS system is that the drying process may affect the gas-to-particle partitioning of semivolatiles and subsequent particle-phase chemistry that may affect the SOA mass yields and chemical composition. However, water uptake of aerosol was accounted for when calculating SOA mass yields in the following method:

Given the flow conditions of the SMPS, particles sizes, in counts per $\mathrm{cm}^{3}$, are recorded in 64 size bins for particles in the 18 to $947 \mathrm{~nm}$ size range. This can be translated into total particle volumes per $\mathrm{cm}^{3}$, and via particle densities to a total suspended particulate (TSP in $\mu \mathrm{g} \mathrm{m}^{-3}$ ). TSP that is the sum of seed aerosol (which is ammonium sulfate (AS) in this work), particle liquid water content (LWC), and SOA:

$\mathrm{TSP}=\mathrm{AS}+\mathrm{LWC}+\mathrm{SOA}$

At the beginning of each experiment, there was no SOA in the chamber, and thus initially,

$\mathrm{TSP}_{0}=\mathrm{AS}_{0}+\mathrm{LWC}_{0}$

A relationship between water uptake on ammonium sulfate particles and RH was developed from Kamens et al. (2011) based upon previous work (Chan et al., 1992; Kleindienst et al., 1999):

$\mathrm{LWC}=\mathrm{AS} \times f(\mathrm{RH})$

Here $f$ represents a functional relationship between LWC and $\mathrm{RH}$ for $1 \mu \mathrm{g} \mathrm{m}^{-3}$ ammonium sulfate particle mass concentration. Hence,

$$
\begin{aligned}
& \mathrm{TSP}_{0}=\mathrm{AS}_{0}+\mathrm{AS}_{0} \times f\left(\mathrm{RH}_{0}\right)=\mathrm{AS}_{0} \times\left[1+f\left(\mathrm{RH}_{0}\right)\right] \\
& \mathrm{AS}_{0}=\mathrm{TSP}_{0} /\left[1+f\left(\mathrm{RH}_{0}\right)\right]
\end{aligned}
$$

Wall-loss rates of particles at different RH in this smog chamber have been previously explored (Kamens et al., 2011). With known initial ammonium sulfate seed aerosol and their known decay rates under the exact same RH ranges employed in the present experiments, the ammonium sulfate particle mass concentration with time can be calculated, and thus, LWC can be estimated based upon Eq. (3). Therefore, SOA in the smog chamber can be estimated from the following:

$\mathrm{SOA}=\mathrm{TSP}-\mathrm{AS}-\mathrm{LWC}$

The SOA density for isoprene/ $\mathrm{NO}_{\mathrm{x}}$ system is presumed to be $1.4 \mathrm{~g} \mathrm{~cm}^{-3}$ (Kroll et al., 2006; Dommen et al., 2006; $\mathrm{Ng}$ et al., 2008). $1.77 \mathrm{~g} \mathrm{~cm}^{-3}$ and $1.0 \mathrm{~g} \mathrm{~cm}^{-3}$ were used as densities of AS and LWC during the above correction procedure.

Background aerosol filter samples were collected several hours before the initiation of the experiments; specifically, filters were collected from both the humidified and dry sides of the dual chamber under dark conditions, where both sides contained only ammonium sulfate seed aerosols. SOA filter sampling was initiated after the aerosol volume concentration started to increase and before it reaches maximum value as detected by the SMPS. The duration of the background filter sample was one hour at a flow rate between $15-20 \mathrm{~L} \mathrm{~min}^{-1}$, and the duration of the SOA filter sample is two hours. The volumes of air sampled through each set of filter samples were approximately the same (within $1 \%$ ) for the humid and the dry chambers. Gas-phase samples were also collected and analyzed using GC-FID before each experiment began. Both the GC-FID and chemical analysis results (i.e. GC/MS and UPLC/ESI-HR-Q-TOFMS) of background aerosol filters indicated that both the humidified and dry chambers were clean and free of isoprene SOA constituents.

\subsection{Filter sample extraction and analysis}

Borosilicate microfiber filters reinforced with woven glass cloth and bonded with PTFE (PALL Life Sciences, 47-mm diameter, $1.0-\mu \mathrm{m}$ pore size) were collected and each filter was extracted in $5 \mathrm{~mL}$ of high-purity methanol (LC-MS CHROMASOLV-grade, Sigma-Aldrich) by $45 \mathrm{~min}$ of sonication. Each $5 \mathrm{~mL}$ methanol extract was separated in half for further GC/MS and UPLC/ESI-HR-Q-TOFMS analysis. All the methanol extracts were blown dry under a gentle $\mathrm{N}_{2}$ stream at ambient temperature (Surratt et al., 2008). Blank filters were treated in the same manner as the samples. Chemical analyses of both blank and background filters collected from the dual smog chamber before each experiment revealed that no isoprene SOA constituents were present.

Filter extracts were analyzed for polar organic compounds by GC/MS with prior trimethylsilylation. Dried residues were trimethylsilylated by the addition of $100 \mu \mathrm{L}$ of BSTFA + trimethylchlorosilane (99:1 (v/v), Supleco) and $50 \mu \mathrm{L}$ of pyridine (Sigma-Aldrich, $98 \%$, anhydrous), and the resultant mixture was heated for $1 \mathrm{~h}$ at $70^{\circ} \mathrm{C}$. This step 
Table 1. Initial conditions for humid-dry isoprene/ $\mathrm{NO}_{\mathrm{x}}$ experiments conducted in UNC outdoor aerosol chamber ${ }^{\mathrm{a}}$.

\begin{tabular}{|c|c|c|c|c|c|c|c|c|}
\hline $\mathrm{ID}^{\mathrm{b}}$ & $\begin{array}{c}\text { Initial [isoprene] } \\
(\mathrm{ppm})\end{array}$ & $\begin{array}{c}\text { Initial [NO] } \\
(\mathrm{ppm})\end{array}$ & $\begin{array}{l}\text { Initial }\left[\mathrm{NO}_{2}\right] \\
(\mathrm{ppm})\end{array}$ & $\begin{array}{l}\text { Temperature Range } \\
(\mathrm{K})\end{array}$ & $\begin{array}{l}\mathrm{RH} \\
(\%)\end{array}$ & $\mathrm{HC} / \mathrm{NO}_{\mathrm{X}}^{\mathrm{c}}$ & $\begin{array}{c}\text { Initial AS }{ }^{\mathrm{d}} \text { mass } \\
\text { concentration }\left(\mu \mathrm{g} \mathrm{m}^{-3}\right)\end{array}$ & $\begin{array}{c}\text { Max SOA mass } \\
\text { concentration }\left(\mu \mathrm{g} \mathrm{m}^{-3}\right)\end{array}$ \\
\hline $2010 \mathrm{OCT} 15 \mathrm{~N}$ & 0.40 & 0.142 & 0.009 & $282-299$ & $38-15$ & 2.65 & 10.4 & $17.5 \pm 3.9$ \\
\hline 2010OCT15S & 0.43 & 0.138 & 0.001 & $282-299$ & $88-45$ & 3.09 & 11.8 & $8.8 \pm 2.2$ \\
\hline $2010 \mathrm{OCT} 21 \mathrm{~N}$ & 0.79 & 0.253 & 0.001 & $281-303$ & $42-16$ & 3.11 & 29.8 & $60.2 \pm 13.5$ \\
\hline 2010OCT21S & 0.78 & 0.252 & 0.001 & $281-303$ & $85-40$ & 3.08 & 25.0 & $34.4 \pm 8.6$ \\
\hline
\end{tabular}

${ }^{a}$ Outdoor smog chamber temperature varying from 275 to $315 \mathrm{~K} .{ }^{\mathrm{b}}$ Experiment identifier in YYYYMMMDDN/S format, where MMM is the three-letter month initials, DD is the experiment day, YYYY is the experiment year and $\mathrm{N}$ or $\mathrm{S}$ represents chamber side in which experiment was performed $-\mathrm{N}$ : North side, $\mathrm{S}$ : South side. ${ }^{\mathrm{c}} \mathrm{HC} / \mathrm{NO}_{\mathrm{X}}$ represents the ratio of initial isoprene concentration (in ppmV) over initial $\mathrm{NO}_{\mathrm{x}}$ concentration. $\mathrm{d}$ "AS" represents ammonium sulfate seed $\left(0.04 \mathrm{M}\left(\mathrm{NH}_{4}\right) \mathrm{SO}_{4}\right)$ that were injected from a aerosol nebulizer.

converts isoprene SOA containing carboxyl and hydroxyl moieties into volatile trimethylsilyl (TMS) derivatives (Surratt et al., 2010). The TMS derivatives were analyzed by GC/MS equipped with an electron ionization (EI) source that was operated at $70 \mathrm{eV}$ (Hewlett 5890 Packard Series II Gas Chromatograph interfaced to a HP 5971A Series Mass Selective Detector, Econo-Cap ${ }^{\mathrm{TM}}-\mathrm{EC}^{\mathrm{TM}}-5$ column, $30 \mathrm{~m} \times 0.25 \mathrm{~mm} \times 0.25 \mu \mathrm{m}$ ). Details of the operation protocols for the GC/MS technique can be found in Surratt et al. (2010). All samples were analyzed by the GC/MS technique within $24 \mathrm{~h}$ of trimethylsilylation.

Polar and acidic compounds found in isoprene SOA were also analyzed by UPLC/ESI-HR-Q-TOFMS. Dried residues from filter extracts were reconstituted with $150 \mu \mathrm{L}$ of 50:50 $(\mathrm{v} / \mathrm{v})$ solvent mixture of $0.1 \%$ acetic acid in methanol (LCMS ChromaSolv-Grade, Sigma-Aldrich) and $0.1 \%$ acetic acid in water (LC-MS ChromaSolv-Grade, Sigma-Aldrich). The reconstituted residues were shaken and sonicated for $5 \mathrm{~min}$ and then stored at $-20^{\circ} \mathrm{C}$ before analysis. An Agilent 6520 Series Accurate Mass Q-TOFMS instrument, equipped with an ESI source operated in the negative (-) ion mode, was used to chemically characterize and quantify polar and acidic compounds in the filter extracts. Optimum ESI conditions were found using a $3500 \mathrm{~V}$ capillary voltage, 100 $\mathrm{V}$ fragmentor voltage, $62 \mathrm{~V}$ skimmer voltage, $300^{\circ} \mathrm{C}$ gas temperature, $10 \mathrm{~L} \mathrm{~min}^{-1}$ drying gas flow rate, 35 psig nebulizer, 10 psig reference nebulizer, and 35 psig reference mass feed. The ESI-Q-TOFMS instrument acquired mass spectra from $m / z 63$ to 1000 . The high resolution (i.e., mass resolution was $\sim 9,000$ ) and accurate mass capabilities in both MS and MS/MS modes make this instrument a powerful tool of structural elucidation of unknown SOA constituents. The chromatographic separations were carried out using a Waters ACQUITY UPLC HSS (high-strength silica) column $(2.1 \times 100 \mathrm{~mm}, 1.8 \mu \mathrm{m}$ particle size $)$ at $45^{\circ} \mathrm{C}$. The mobile phases consisted of eluent (A) $0.1 \%$ acetic acid in water (LC-MS ChromaSolv-Grade, Sigma-Aldrich) and eluent (B) $0.1 \%$ acetic acid in methanol (LC-MS ChromaSolvGrade, Sigma-Aldrich). The applied 12 min gradient elution program was as follows: the concentration of eluent B was $0 \%$ for the first $2 \mathrm{~min}$, increased to $90 \%$ from 2 to $10 \mathrm{~min}$, held at $90 \%$ from 10 to $10.2 \mathrm{~min}$, and then decreased back to $0 \%$ from 10.2 to $12 \mathrm{~min}$. The flow rate and sample injection volume were $0.3 \mathrm{~mL} \mathrm{~min}^{-1}$ and $5 \mu \mathrm{L}$, respectively. Data were acquired and analyzed by Mass Hunter Version B.03.01 Build 3.1.346.0 software. At the beginning of each analysis period, the Q-TOFMS instrument was calibrated using a commercially available ESI-L low concentration tuning mixture (Agilent Technologies), which was composed of a 95:5 $(\mathrm{v} / \mathrm{v})$ solvent mixture of acetonitrile and water. This external calibration was done in the low-mass range $(m / z<1700)$. Six specific ions were used from the commercial tuning mixture during calibration, and include: 112.985587, 301.998139, 601.978977, 1033.988109, 1333.968947, and 1633.949786 Da. During the chromatographic runs, the Q-TOFMS was continually calibrated by the constant injection of the following reference compounds in the ESI source: purine, leucine enkephalin, and HP-0921 acetate adduct (Agilent Technologies).

\section{Results and discussion}

\subsection{Gas-phase and SMPS results}

To make RH the only significant difference between each set of experiments, almost identical gas-phase conditions are required. Table 1 lists the two sets humid-dry experiments that were performed in the dual outdoor smog chamber. The first set of experiments (2010OCT15N and 2010OCT15S) used $\sim 0.4 \mathrm{ppm}$ isoprene, $\sim 0.14 \mathrm{ppm} \mathrm{NO}_{\mathrm{x}}$, and $\sim 10 \mu \mathrm{g} \mathrm{m}^{-3}$ ammonium sulfate seed aerosol as initial conditions; the second set of experiments (2010OCT21N and 2010OCT21S) approximately doubled the concentrations but kept the initial isoprene/NO ratio $(\sim 3)$ the same as the first set of experiments. In the two dry experiments, the RH started at $\sim 40 \%$ and decreased to $\sim 15 \%$ by midday; for the humid experiments, the RH started at $\sim 90 \%$, with no water condensation observed on the chamber walls, and dropped to $\sim 40 \%$ during the day. Figure 1a shows the gas-phase measurements obtained from the second set of experiments. Identical $\mathrm{O}_{3}$, $\mathrm{NO}_{\mathrm{x}}$ and isoprene profiles were observed between the dry (North $[\mathrm{N}]$ ) and the humid (South $[\mathrm{S}]$ ) chambers. 

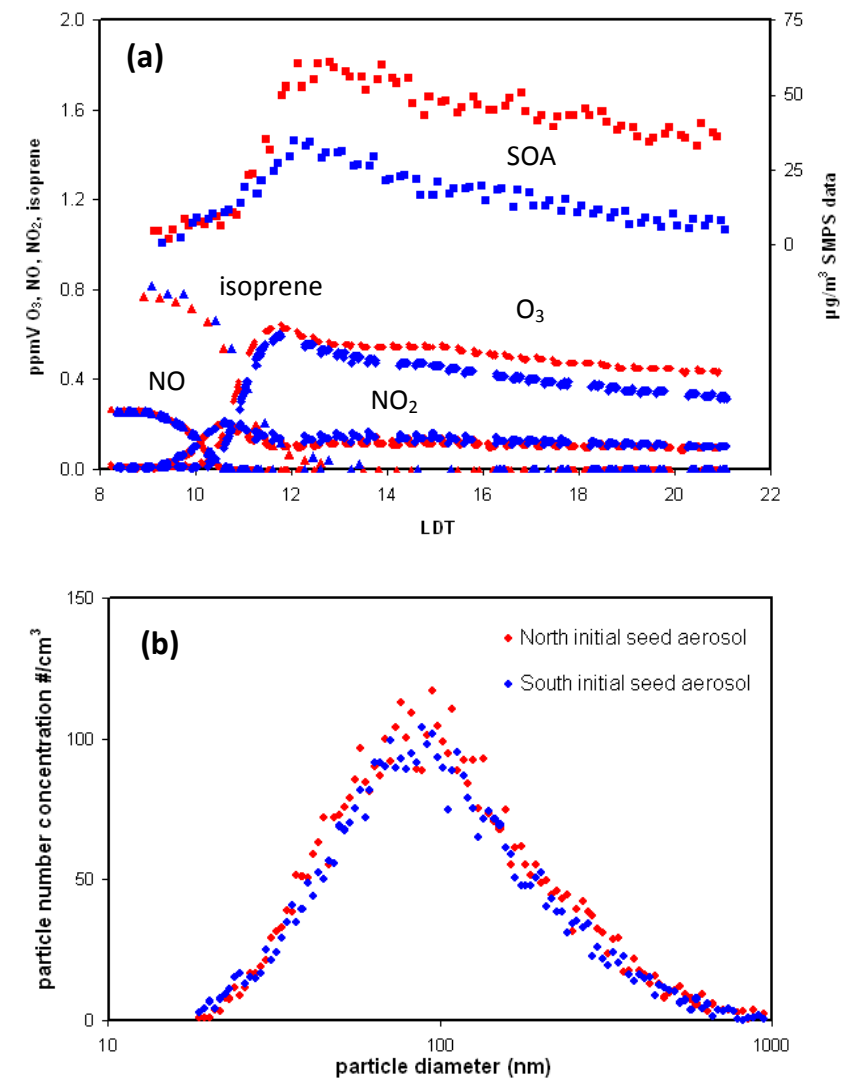

Fig. 1. (a) Gas-phase measurement of $\mathrm{O}_{3}, \mathrm{NO}_{\mathrm{x}}$, and isoprene and wall-loss uncorrected SOA data. (b) Particle size distributions under low- and high-RH conditions when the experiments began. The red dots are data from the North chamber (2010OCT21N, low-RH condition); the blue dots are data from South chamber (2010OCT21S, high-RH condition).

Also shown in Fig. 1a are the SOA mass in the smog chamber (wall-loss uncorrected) vs. time presented in particle mass concentration for the humid-dry experiments. On 2010OCT21, the dry side started with $29.8 \mu \mathrm{g} \mathrm{m}^{-3}$ of the ammonium sulfate seed aerosol, and upon photooxidation, reached a maximum SOA mass concentration of $60.2 \mu \mathrm{g} \mathrm{m}^{-3}$, with a SOA yield of $3.0 \%( \pm 0.7 \%)$; the humid side started with $25.0 \mu \mathrm{g} \mathrm{m}^{-3}$ of ammonium sulfate seed aerosol, and upon photooxidation, SOA peaked at $34.4 \mu \mathrm{g} \mathrm{m}^{-3}$, with a SOA yield of $1.6 \%( \pm 0.4 \%)$. In the other set of experiments with relatively lower initial concentrations, the dry side SOA maximum is $17.5 \mu \mathrm{g} \mathrm{m}^{-3}$, with a SOA yield of $1.5 \%( \pm 0.3 \%)$, and the humid side SOA maximum is $8.8 \mu \mathrm{g} \mathrm{m}^{-3}$, with a SOA yield of $0.7 \%( \pm 0.2 \%)$. As a result, with approximately identical initial conditions, isoprene-derived SOA formed under low-RH conditions between $15-40 \%$ can be a factor of two higher than that formed under high-RH conditions between 40-90\%. As can be observed from Fig. 1a, the SOA mass concentrations decreased after reaching the maximum growth. These SOA mass decreases are likely due to the following possibilities: (1) Wall losses of particles; (2) Temperature increases observed during the course of the experiments could have evaporated semivolatile/volatile organics back into the gas phase; (3) Organic peroxides could have formed after the initial NO concentration dropped to zero, and as a result, the $\mathrm{RO}_{2}+\mathrm{NO}$ gas-phase reactions no longer dominated. Instead, since isoprene was still abundant around the time NO dropped to zero (i.e., $\sim 500 \mathrm{ppb}$ of isoprene still remaining), the $\mathrm{RO}_{2}$ radicals that formed from further $\mathrm{OH}$-initiated reactions of isoprene likely reacted either by $\mathrm{RO}_{2}+\mathrm{RO}_{2}$ or $\mathrm{RO}_{2}+\mathrm{HO}_{2}$ pathways, resulting in organic peroxide formations (ROOR or $\mathrm{ROOH}$ types). Aerosol-phase organic peroxides could have resulted and these have been shown to quickly photolyze after reaching the peak in aerosol formation in previous chamber studies that examined isoprene photooxidation under low- $\mathrm{NO}_{\mathrm{x}}$ conditions (Kroll et al., 2006; Surratt et al., 2006); (4) Finally, heterogeneous oxidation of the aerosol could have resulted in the evaporation of organic material from the aerosol phase, as shown in recent studies (e.g., George and Abbatt, 2010; Kroll et al. 2009). The exact cause of these decreases will be examined in future work. Figure $1 \mathrm{~b}$ shows the initial particle size distributions of both the dry and humid experiments on 2010OCT21. These initial size distributions indicate that both sides had a similar number of particles. The other set of experiments had similar results and are shown in Fig. 1S (see Supplement). The error analysis of the maximum SOA mass and SOA yield will also be found in the Supplement.

Comparing the SOA yields under high- $\mathrm{NO}_{\mathrm{x}}$ conditions found in the present study with several previous studies (Kroll et al., 2005, 2006; Dommen et al., 2006), the data in this study lie close to the data from Dommen et al. (2006), as shown in Fig. 2. Note that among these four studies, the experiments performed by Dommen et al. (2006) did not use initial seed aerosol and the other three studies use ammonium sulfate as seed aerosol. As noted by Kroll et al. (2007), SOA yields are relatively lower in the system where inorganic seed aerosols are not initially present. This could potentially explain the lower SOA yields observed in the Dommen et al. (2006) study. The high- $\mathrm{NO}_{\mathrm{x}} \mathrm{SOA}$ yields presented by the Kroll et al. (2005, 2006) studies are relatively higher than this study that can be attributed to several reasons: (1) The SOA data reported in this study is not wall-loss corrected, and thus the SOA yields are likely under predicted, which may explain why SOA yields in this study are almost as low as the Dommen et al. (2006) study reported, even though seed aerosol was employed in this study; (2) OH radical precursor may also affect SOA yield. Kroll et al. (2006) used the photolysis of $\mathrm{H}_{2} \mathrm{O}_{2}$ as an $\mathrm{OH}$ radical source and Kroll et al. (2005) used HONO photolysis to generate both $\mathrm{OH}$ radical and NO. However, Dommen et al. (2006) used xenon arc lamps to simulate solar light and this work was performed under natural sunlight. An extra source of $\mathrm{OH}$ radicals could also enhance SOA formation and hence, the SOA yield of the Dommen et al. (2006) and this work are relatively lower than the Kroll et al. (2005, 2006) results; (3) Systematical 


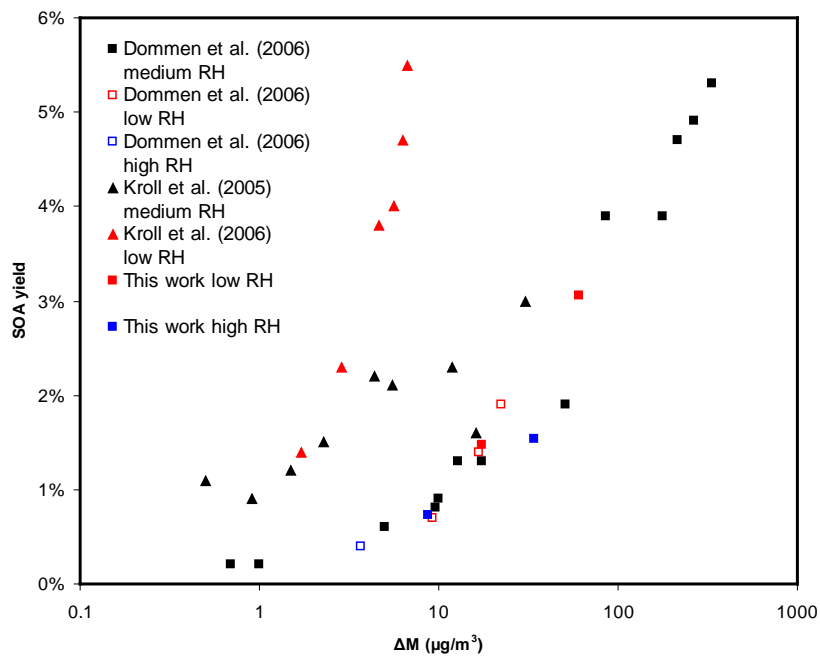

Fig. 2. Summary of SOA yields under isoprene high- $\mathrm{NO}_{\mathrm{x}}$ conditions reported from previous literature and this work as a function of organic mass concentration $(\Delta \mathrm{M})$. The SOA density was assumed to be $1.35 \mathrm{~g} \mathrm{~cm}^{-3}$ in Kroll et al. (2006) high- $\mathrm{NO}_{\mathrm{x}}$ conditions. The other studies used SOA density of $1.40 \mathrm{~g} \mathrm{~cm}^{-3}$. The temperature in this work varied from $\sim 10^{\circ} \mathrm{C}$ to $\sim 30^{\circ} \mathrm{C}$; the temperature in the other studies were stable at $20-22^{\circ} \mathrm{C}$.

conditions such as temperature can be a possible reason as well. It should also be noted that the Kroll et al. $(2005,2006)$ studies were based upon the same chamber system except that the Kroll et al. (2005) experiments are performed under $40 \%<\mathrm{RH}<50 \%$, while the Kroll et al. (2006) experiments are performed under $\mathrm{RH}<10 \%$. From Fig. 2, the experiments in Kroll et al. (2006) study showed higher yields than the similar experiments in Kroll et al. (2005) study. By comparing the two Kroll et al studies one may surmise there is an RH effect on isoprene SOA formation, but unfortunately these two studies had different sources of $\mathrm{OH}$ radicals and NO. This study, however, directly addressed RH effects and our observations reinforce the combined RH-SOA implications of Kroll et al. (2005, 2006).

Dommen et al. (2006) examined the effect of varying the initial isoprene/ $/ \mathrm{NO}_{\mathrm{x}}$ ratio on $\mathrm{SOA}$ formation from isoprene; the specific focus was on examining this effect on SOA yields, the presence of oligomers, and on the volatility of the resultant SOA. However, in a few circumstances, they examined the effect of varying $\mathrm{RH}$ under similar initial $\mathrm{VOC} / \mathrm{NO}$ ratios. One pair of their experiments had an initial VOC/NO ratio of $\sim 7$ and in another pair of experiments this ratio was $\sim 5-6$. In both pairs, the dry experiments had an $\mathrm{RH}<2 \%$, whereas the more humid experiments had an RH of about $53 \%$. The SOA yields observed in the drier experiments were found to be higher by a factor of about 2 . Interestingly, for the experiments that had an initial $\mathrm{VOC} / \mathrm{NO}$ ratio of about $5-6$, the SOA was found to have a much lower volatility under dry conditions, which was consistent with the observa- tion of oligomeric SOA constituents found in Dommen et al. (2006). These results further support our findings.

\subsection{Chemical composition of SOA}

Since the filter sampling volumes $\left(5.82 \mathrm{~m}^{3}\right.$ vs. $5.89 \mathrm{~m}^{3}$; $6.37 \mathrm{~m}^{3}$ vs. $6.44 \mathrm{~m}^{3}$ ) and the extraction efficiencies were similar, chromatographic peak areas can be directly compared. The experiments of 2010OCT15N and 2010OCT15S that were conducted under relatively lower initial concentrations have similar results to the other set of experiments but less intense chromatographic peaks, and their associated GC/MS and UPLC/ESI-HR-Q-TOFMS results are shown in Figs. 2S and $3 S$ (see Supplement), respectively.

TMS derivatives of the filter extracts were chemically analyzed by GC/MS. Figure 3a compares the total ion chromatograms (TICs) of aerosol filter extracts obtained from the low (2010OCT21N)- and the high (2010OCT21S)-RH experiments. The red and blue lines represent TICs of low- and high-RH filter extracts, respectively. The two diastereoisomeric 2-methyltetrols, which include 2-methylthreitol and 2-methylerythritol, had retention times (RT) of 31.1 and 31.9 min, respectively, and have similar chromatographic peak areas in both the low- and high-RH chambers. However, the chromatographic peak area of 2-MG (RT $\sim 21.7 \mathrm{~min}$ ) was much higher in the dry experiment compared to the humid experiment. Also, more peaks were observed between 35 $50 \mathrm{~min}$ (associated with oligoesters) in the dry side. In particular, the peak areas of diesters derived from the esterification of two 2-MG residues (RT $\sim 43-45 \mathrm{~min}$ ) (Surratt et al., 2006; Szmigielski et al., 2007) were higher in the dry experiments by a factor of $\sim 5$. It is noted from the TIC comparison that an unknown tracer was substantially enhanced in the dry experiment (RT $\sim 25 \mathrm{~min}$ ), which has a higher peak area than both the 2-methyltetrols and 2-MG. The GC/MS EI mass spectrum of this unknown tracer is shown in Fig. 3b. Although we did not observe this unknown tracer on any of our control filters, we cannot completely rule out that this unknown tracer is not due to an artifact of the GC/MS analyses. Further chemical analyses will be needed to verify if this is a result of a GC/MS artifact.

Due to the lack of available authentic standards for most isoprene SOA constituents, quantification was performed by using a surrogate standard (i.e., meso-erythritol) for the 2methyltetrols as well as for the other isoprene SOA constituents observed by the GC/MS technique. Table 2 shows the quantification results from the GC/MS technique for the major SOA components (extraction efficiencies not included). The identification of these compounds was based on EI mass spectra (shown in Fig. 4S, see Supplement) and their consistency with previous studies (Edney et al., 2005; Surratt et al., 2006, 2010; Szmigielski et al., 2007). The relative lower yield of the unknown tracer under low-RH condition for $2010 \mathrm{OCT} 15 \mathrm{~N}$ is probably due to the lower initial 


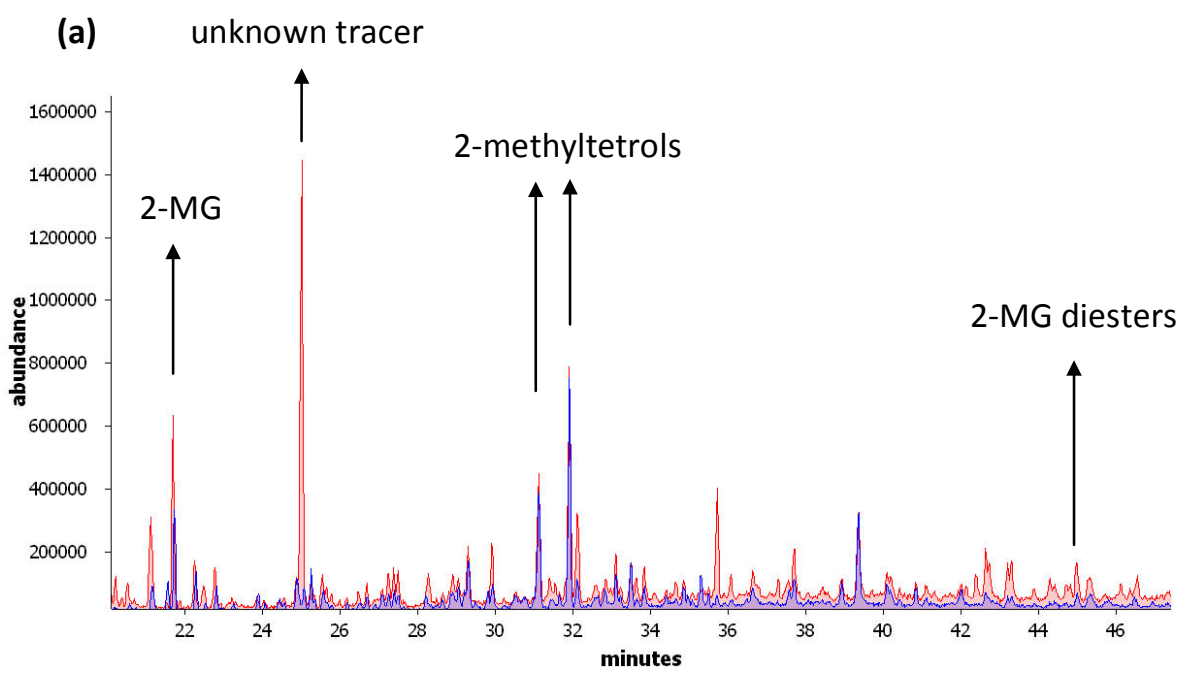

(b)

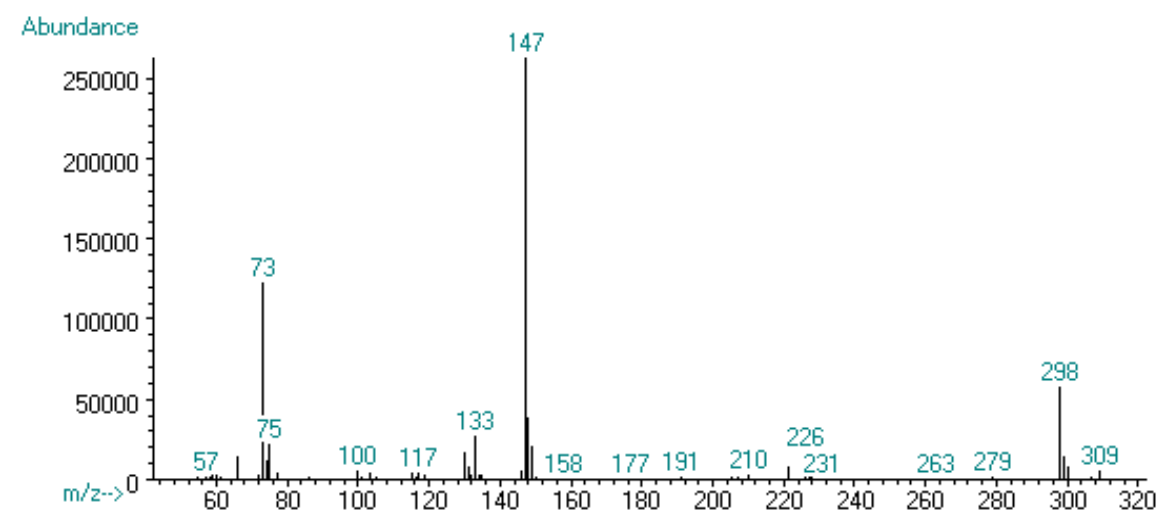

Fig. 3. (a) Comparison of GC/MS TICs of the filter extracts of 2010OCT21N (low-RH experiment, red lines) and 2010OCT21S (high-RH experiment, blue lines). Important isoprene-derived SOA compounds (i.e., 2-MG, the unknown tracer, 2-methyltetrols, and 2-MG diesters) are labeled. (b) EI mass spectrum associated with the unknown tracer peak in (a).

Table 2. Mass concentrations of major SOA compounds based on GC/MS results. (Unit: $\mathrm{ng} \mathrm{m}^{-3}$ ).

\begin{tabular}{lllll}
\hline & \multicolumn{5}{c}{ Experiment ID } \\
\hline Compound & 2010 OCT15N & 2010 OCT15S & 2010OCT21N & 2010OCT21S \\
2-MG & 17.9 & 10.1 & 54.0 & 28.7 \\
C5alkenetriols & 3.4 & 1.3 & 35.5 & 21.0 \\
Unknown tracer & 4.3 & 1.5 & 146.4 & 8.3 \\
2-methyltetrols & 19.2 & 13.3 & 132.2 & 117.8 \\
2-MG oligoesters & 13.8 & 2.0 & 33.8 & 6.9 \\
\hline
\end{tabular}

concentration of isoprene employed compared to the higher concentration experiment (2010OCT21N).

Filter extracts were analyzed by the UPLC/(-)ESI-QTOFMS technique and quantified for polar and acidic SOA components. Figures $4 \mathrm{a}-\mathrm{h}$ compare the UPLC/(-)ESI-HR-
Q-TOFMS extracted ion chromatograms (EICs) between the low (2010OCT21N)- and the high (2010OCT21S)-RH filter extracts. The red and blue lines represent EICs of lowand high-RH filter extracts, respectively. Figure $4 \mathrm{a}-\mathrm{f}$ represent comparisons of $2-\mathrm{MG}\left([\mathrm{M}-\mathrm{H}]^{-}=119\right)$, the diesters 

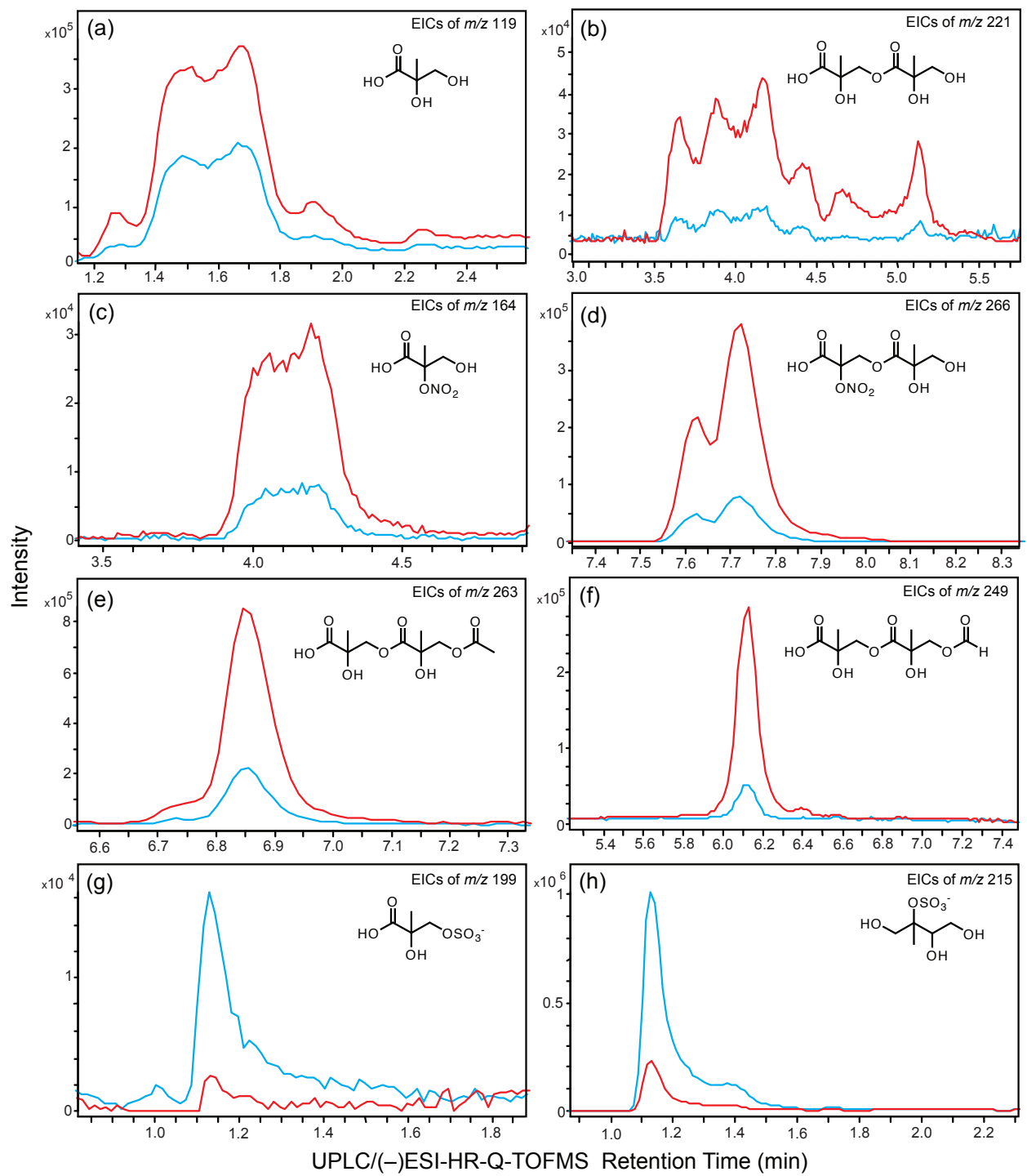

Fig. 4. Comparison of known isoprene SOA constituents produced from isoprene oxidation under initially high-NO and high-RH (blue lines) and low-RH (red lines) conditions in the presence of neutral ammonium sulfate seed aerosol. For simplicity, only one structural isomer is shown. All of the MPAN-derived SOA products $(\mathbf{a}-\mathbf{f})$, except for $\mathbf{g}$, are found to increase in abundance under low-RH conditions. All of the organosulfates derived from isoprene oxidation were found to increase in abundance with increasing RH, including the organosulfate derived from IEPOX (h) and also from glyoxal (Fig. 5S, see Supplement). ESI-HR-Q-TOFMS accurate measurements show that the elemental compositions of these compounds are consistent with the proposed structures (see Supplement, Table 1S).

formed from two 2-MG residues $\left([\mathrm{M}-\mathrm{H}]^{-}=221\right)$, an acidic organic nitrate monomer $\left([\mathrm{M}-\mathrm{H}]^{-}=164\right)$, the diesters derived from the esterification 2-MG and the acidic organic nitrate monomer $\left([\mathrm{M}-\mathrm{H}]^{-}=266\right)$, a trimer species formed from the esterification of two 2-MG residues with acetic acid $\left([\mathrm{M}-\mathrm{H}]^{-}=263\right)$, and a trimer species formed from the esterification of two 2-MG residues with formic acid ([M $\mathrm{H}]^{-}=249$ ), respectively. In all the above comparisons, the low-RH experiment has higher chromatographic peak areas by factors of 2 to 4 . The oligoesters composed solely of organic nitrate monomers (residues) were likely not detected from the UPLC/(-)ESI-Q-TOFMS technique due to the hydrolysis of the $-\mathrm{ONO}_{2}$ group(s) into $-\mathrm{OH}$ group(s) during sample workup and/or analysis (Sato, 2008). Part of the acetate triester (Fig. 4e) formation could be due to the presence of the acetic acid in the mobile phase; however, the detection of the formate triester (Fig. 4f) indicates that this is a real effect and that at least some fraction of the acetate triester is due to acetate produced during the oxidation of isoprene (Surratt et al., 2006, 2010). Prior studies have also observed and characterized oligoesters containing formate and acetate residues in isoprene SOA (Surratt et al., 
2006, 2010; Szmigielski et al. 2007; Chan et al., 2010), which is consistent with the accurate mass data (i.e., elemental compositions) obtained in the present study (see Table 1S, Supplement). Additionally, Angove et al. (2006) have observed formate esters from the photooxidation of butadiene in the presence of $\mathrm{NO}_{\mathrm{x}}$. In addition to the oligoesters, we also observed organosulfates derived from 2-MG (i.e., $[\mathrm{M}-\mathrm{H}]^{-}$ion at $m / z$ 199) and from IEPOX $\left([\mathrm{M}-\mathrm{H}]^{-}\right.$ ion at $m / z$ 215)) using the UPLC/ESI-HR-Q-TOFMS technique shown in Fig. $4 \mathrm{~g}$ and $\mathrm{h}$, respectively. Surprisingly, these organosulfates are higher for the humid experiments; the organosulfate derived from glyoxal was also observed to be higher in the humid experiments (Fig. 5S, see Supplement). Although previous studies have shown that organosulfates derived from isoprene oxidation are enhanced under acidic conditions (Surratt et al., 2007a, b, 2010; GómezGonzález et al. 2008), these studies were conducted primarily under dry conditions ( $\mathrm{RH}<30 \%$ ). Recent studies have shown that aerosol acidity is not always necessary to form organosulfates (Galloway et al., 2008; Perri et al., 2010; Nozière et al., 2010); more specifically, these studies have shown that organosulfates can form from the irradiation of aqueous aerosols that contain sulfate possibly due to radicalinitiated reactions in the wet aerosols.

The GC/MS and UPLC/(-)ESI-HR-Q-TOFMS results are consistent in that both 2-MG and its corresponding oligoesters were enhanced in the low-RH experiments. Based upon the chemical composition analysis, a tentative proposal of the identification of the unknown tracer observed in the GC/MS data is possible. The EI mass spectrum of this unknown tracer in GC/MS suggests that it has at least one $\mathrm{OH}$ group and a trimethylsilylated molecular weight (MW) of 309 , which also implies that it contains an odd number of nitrate groups due to the odd MW of the TMS derivative. The GC/MS retention time of this tracer suggests a $\mathrm{C}_{4}$ or $\mathrm{C}_{5}$ compound, and thus, the number of $-\mathrm{OH}$ groups is most likely to be two, resulting in the MW of the unknown tracer to be 165. Using the UPLC/(-)ESI-HR-Q-TOFMS technique, a compound with a MW of 165 was detected as a deprotonated ion and its elemental composition was determined to be $\mathrm{C}_{4} \mathrm{H}_{6} \mathrm{NO}_{6}^{-}$(Fig. 4c), which is consistent with the GC/MS result. Hence, this hypothesized nitrate compound, with a $\mathrm{C}_{4}$ backbone structure, is very similar to $2-\mathrm{MG}$, except that one of the $-\mathrm{OH}$ groups is replaced with a $-\mathrm{ONO}_{2}$ group. This hypothesis also explains the correlation that when the peak areas of the tracer are high those of 2-MG are also high, because a certain fraction of 2-MG may form from the hydrolysis of this speculated nitrate monomer. If this is the case, however, the GC/MS mass spectrum (Fig. 3b) associated with this tracer cannot be fully explained, especially the fragment ion observed at $m / z$ 298. It is possible that the unknown tracer is not acidic, and as a result, was not detected by the UPLC/(-)ESI-HR-Q-TOFMS technique. Additionally, it is possible that the nitrate group of the UPLC/(-)ESI-HR-Q-TOFMS detected MW 165 compound was trimethylsilylated the same way as the $-\mathrm{OH}$ group on 2-MG, and as a result, was detected as the same structure as 2-MG by the GC/MS technique; however, if the latter was true then the unknown N-containing tracer should not have been observed by the GC/MS technique as a considerable peak, especially if it was an organic nitrate group. This suggests that the unknown tracer is more consistent with the hypothesis of a $\mathrm{C}_{4} \mathrm{H}_{7} \mathrm{NO}_{6}$ compound. Although $\mathrm{C}_{4} \mathrm{H}_{7} \mathrm{NO}_{6}$ is the likely composition of this unknown tracer, we cannot completely rule out the possibility that this unknown tracer has a $\mathrm{C}_{5} \mathrm{H}_{11} \mathrm{NO}_{5}$ formula. However, if this is the structure of the unknown tracer, it must have one $-\mathrm{ONO}_{2}$ group and likely two -OH groups. This composition is very hard to argue from known gas-phase chemistry of isoprene under initially high-NO conditions. During the atmospheric photooxidation or the filter extraction process, $-\mathrm{ONO}_{2}$ groups could be hydrolyzed, resulting in the formation an -OH group (Sato et al., 2008). Thus, the hydrolyzed compound would be $\mathrm{C}_{5} \mathrm{H}_{12} \mathrm{O}_{3}$ with three $-\mathrm{OH}$ groups, with a MW 120 (or MW 336 after trimethylsilylation). If this is the case, since the unknown tracer has a large peak area, this hydrolyzed compound should also have a relatively high concentration and have been observed directly by GC/MS. However, the only trimethylsilyated compound with MW 336 observed by GC/MS is the trimethylsilylated 2-MG, which has a different structure from this $\mathrm{C}_{5} \mathrm{H}_{12} \mathrm{O}_{3}$. By contrast, if the unknown tracer is what we have proposed, the hydrolyzed compound is 2-MG, which explains why we did not see another MW 120 (or trimethylsilyated MW 336) compound by GC/MS analyses.

Jaoui et al. (2010) reported a similar N-containing SOA tracer under acidic conditions in both chamber-generated and ambient organic aerosol using GC/CI-MS, which likely had a trimethylsilylated MW of 313 . The latter can better explain the fragment ion at $m / z 298$ (fragmentation of a methyl group from the molecular ion) in Fig. 3b. However, Jaoui et al. (2010) still could not provide a reasonable structure of the unknown isoprene tracer. Furthermore, a $\mathrm{C}_{4} \mathrm{H}_{7} \mathrm{NO}_{6}$ compound is hard to explain by the trimethylsilylated MW of 313 observed by Jaoui et al. (2010). If the unknown tracer observed by both Jaoui et al. (2010) and in the present study are further proved to be identical, the result of the present work will be significant because the unknown tracer observed by Jaoui et al. (2010) has been measured in several ambient aerosol samples.

To further identify and confirm the structure of this unknown tracer, more advanced analytical techniques, such as GC/EI-HR-TOFMS, are needed as well as synthesis of an authentic standard. Nevertheless, the chemical composition results obtained in the present study already reveal the importance of a $\mathrm{C}_{4}$-preserving pathway (i.e., the further oxidation of MPAN leads to 2-MG and its corresponding oligoesters) that leads to the enhanced SOA formation from isoprene under low-RH conditions. 


\subsection{MPAN oxidation and role of organic esterification chemistry}

The detailed gas-phase oxidation reactions of isoprene that lead to the formation of MACR and MPAN have been well characterized by previous studies (Paulson et al., 1992a, b; Bertman and Roberts, 1991; Orlando et al., 2002). The importance of the further oxidation of MPAN under high$\mathrm{NO}_{\mathrm{x}}$ conditions in leading to the formation of isoprene SOA have been demonstrated recently by Surratt et al. (2010) and Chan et al. (2010). However, the detailed chemistry following MPAN oxidation that leads to isoprene SOA formation, and thus 2-MG and its corresponding oligoesters, remains unclear and different intermediate products have been suggested by these previous studies.

In this paper, we do not have adequate information to validate the structures of the previously proposed gas-phase intermediate products; however, it is believed that the reactive gaseous intermediate produced by the further gas-phase oxidation of MPAN undergoes gas-aerosol partitioning, further reacts in the particle phase, and ultimately forms the unknown SOA tracer discussed above from the GC/MS data. Furthermore, this unknown reactive intermediate likely undergoes organic esterification in the particle phase, which ultimately forms the oligoesters observed by both the GC/MS and UPLC/ESI-HR-Q-TOFMS techniques. The formation of oligoesters will reduce the monomer concentration in the aerosol phase, and further drive gas-particle partitioning, and increase SOA formation. If the unknown SOA tracer observed in the GC/MS data is what we have hypothesized, both the monomer and its oligoesters can be hydrolyzed to form 2-MG and its corresponding oligoesters during the experiment and/or the extraction process.

The feasibility of the atmospheric organic esterification process has been theoretically studied by Barsanti and Pankow (2006), indicating that ester formation is thermodynamically favored and likely to occur if kinetically favored. Since water is a product in esterification reactions, lower $\mathrm{RH}$ tends to promote ester formation to different extents for different carboxylic and dicarboxylic acids. In addition, Dommen et al. (2006) examined isoprene SOA formation under $\mathrm{NO}_{\mathrm{x}}$ conditions but could not explain the observed lower volatility of isoprene SOA produced under lower RH conditions ( $0 \%$ vs. $50 \%$ ); however, the proposed organic esterification process presented in our study could explain the differences in their volatility measurements.

It is important to also note that 2-MG and its corresponding oligoesters have been chemically characterized at the molecular level using GC/MS with prior single derivatization (i.e., trimethylsilylation only) or double derivatization (i.e., ethylation followed by trimethylsilylation) approaches (Surratt et al., 2006; Szmigielski et al., 2007), LC/ESI-MS/MS or LC/ESI-HR-TOFMS techniques (Surratt et al., 2006; Chan et al., 2010; Nguyen et al., 2011; Sato et al., 2011), and more recently by high-resolution AMS (Chan et al., 2010; Sato et al., 2011). The GC/MS with prior single or double derivatization approaches have helped to tag the ester linkages to further support the LC/ESI-HR-TOFMS, LC/ESI-MS/MS, and more recently the HR-AMS data. Thus, currently, it is very difficult to argue against the identity of these oligomers as oligoesters; however, these compounds have not been fully confirmed owing to the lack of authentic standards.

Last, we want to add that the oxidation of other VOCs, such as cyclohexene ozonlysis (Hamilton et al. 2006; Müller et al., 2008), cyclohexene/ $\alpha$-pinene ozonolysis (Müller et al., 2008), $\alpha$ - $\beta$-unsaturated aldehydes (e.g., acrolein, crotonaldehyde, MACR) photooxidations under initially high $\mathrm{NO}_{2} / \mathrm{NO}$ ratios (Chan et al., 2010), and 1,3-butadiene photooxidation under high- $\mathrm{NO}_{\mathrm{x}}$ conditions (Angove et al., 2006; Sato et al., 2011), have been shown to lead to oligoesters in the resultant SOA. Most of these prior systems have been investigated under dry conditions.

Particle-phase organic esterification is likely to be an acidcatalyzed process (Surratt et al., 2006; Szmigielski et al., 2007), which raises an important question: is acidity required in order to enhance SOA formation through the tentatively proposed organic esterification pathway? In the present study, the acidity effect is concluded not to contribute to SOA enhancements under dry conditions if aerosol acidity is assumed to only stem from the atomized ammonium sulfate seed aerosols. The latter is due to the fact that the $\mathrm{pH}$ of ammonium sulfate aerosols cannot be lower than 5 , which is the saturation value, and this value cannot change significantly in the $\mathrm{RH}$ regime investigated in this study $(\mathrm{Xu}$ et al., 1998). However, we cannot rule out the possibility that nitric acid $\left(\mathrm{HNO}_{3}\right)$ absorbed onto aerosols during the course of the experiments, and thus, increased the particlephase acidity needed to drive organic esterification reactions forward. Previous work by Lim and Ziemann (2009) found that $\mathrm{HNO}_{3}$ uptake onto organic particles might provide the necessary acidity to conduct certain heterogeneous reactions (i.e., acid-catalyzed isomerizations of 1,4-hydroxycarbonyls and dihydroxycarbonyls to cyclic hemiacetals). Furthermore, it has been shown that $\mathrm{HNO}_{3}$ absorbs and dissociates on hydrophobic organic surfaces (Handley et al., 2007), and as a result, $\mathrm{HNO}_{3}$ could likely be a source of acidic protons on SOA and chamber walls.

In addition, the formation of 2-methyltetrols was not significantly enhanced in the low-RH experiments. Surratt et al. (2007b, 2010) and Jaoui et al. (2010) both found under acidic conditions (acidity introduced by either acidic sulfate seed aerosol or injection of gaseous $\mathrm{SO}_{2}$ ) that the 2methyltetrols as well as the SOA mass were enhanced, but the formation of 2-MG remained fairly constant, which is contrary to the results of the present study. In this study, the formation of 2-methyltetrols was similar in both the highand low-RH experiments, but the formation of 2-MG (and its corresponding oligoesters) increased by as much as a factor of two in the low-RH experiments. These opposite results indicate that it is more likely that low $\mathrm{RH}$ is playing a major 
role in accounting for the higher SOA yields through the particle-phase organic esterification process under dry conditions. Nevertheless, it is also possible that alternative mechanisms can explain the enhanced formation of the oligoesters. Further study is needed to confirm the exact processes leading to the enhanced formation of 2-MG and its corresponding oligoesters under dry conditions.

\section{Atmospheric implications and conclusion}

The unexpected findings presented above suggest that higher MPAN-derived SOA yields result from isoprene photooxidation under low-RH conditions. Thus, if the results in the present study are further confirmed, isoprene-derived SOA yields in the atmosphere could be lower than most of current chamber studies suggest; this would be especially true in isoprene-influenced urban areas with high- $\mathrm{NO}_{\mathrm{x}}$ concentrations because atmospheric RH tends to be higher than most of the previous chamber studies. It is important to note that these prior chamber studies are typically used to estimate isoprene associated SOA (Surratt et al., 2006, 2007b, 2010; Kroll et al., 2005, 2006).

Furthermore, the results found in this study are opposite to recent RH effect studies on aromatic systems (Kamens et al., 2011; Zhou et al., 2011), suggesting different chemical channels for the different SOA precursors. Under varied $\mathrm{RH}$ conditions, several possible factors affecting SOA yield have been suggested in this work. The particle-phase organic esterification is speculated to have a major role and "drives" the difference of SOA yields under the investigated low- and high-RH conditions. Organosulfates, on the other hand, have higher yields under humid conditions due to the potential need for particle-phase water. Volkamer et al. (2009) and Ervens and Volkamer (2010) demonstrated that water uptake of glyoxal and methylglyoxal onto pre-existing aerosols contribute to larger SOA mass at higher RH. However, this work proposed a conflicting chemical process and the present results indicate that aqueous-phase chemistry of glyoxal and methylglyoxal is not the only SOA formation pathway affected by RH. Furthermore, in the system of isoprene/NO photooxidation, water uptake of glyoxal and methylglyoxal is not as important as the tentatively proposed organic esterification process. Nevertheless, it is also possible that the RH difference in this study (i.e. $\sim 40 \%$ ) is not large enough to generate a sufficient aqueous-phase SOA difference. In addition, gas-phase yields of glyoxal and methylglyoxal can also affect aqueous-phase SOA. Therefore, when the initial isoprene/NO ratio and RH difference vary, aqueous-phase SOA may play a more important role. In the atmosphere, $\mathrm{NO}_{\mathrm{x}}$ concentration, acidity, and sulfate conditions are highly variable. How these factors affect isoprene-derived SOA yield under different RH conditions will be a significant issue in future studies. For example, under low- $\mathrm{NO}_{\mathrm{x}}$ conditions the proposed organic esterification will not be sig- nificant whereas the reactive uptake of IEPOX will likely yield most of the isoprene SOA (Surratt et al., 2010), and thus, the impacts of $\mathrm{RH}$ on this latter pathway require further study. Oligomerization of glyoxal and methylglyoxal and organosulfate formation are probably both enhanced under high-RH conditions, and assuming acidity differences caused by RH is still insignificant, SOA yields may be higher under high- $\mathrm{RH}$ conditions for low- $\mathrm{NO}_{\mathrm{x}}$ oxidations.

\section{Supplement related to this article is available online at: http://www.atmos-chem-phys.net/11/6411/2011/ acp-11-6411-2011-supplement.pdf.}

Acknowledgements. This research was supported by an NSF grant (ATM-0711097) to the University of North Carolina. UPLC/ESI-HR-Q-TOFMS analyses were conducted in the UNC$\mathrm{CH}$ Biomarker Mass Facility located within the Department of Environmental Sciences and Engineering, which is a part of the UNC-CH Center for Environmental Health and Susceptibility and is supported by NIEHS (Grant 5P20-ES10126 - J. A. Swenberg is the PI). Thanks to Caitlin Rubitschun for helping to operate the UPLC/(-)ESI-HR-Q-TOFMS instrument. We would also like to thank the reviewers of our manuscript for helpful suggestions.

Edited by: A. S. H. Prévôt

\section{References}

Altieri, K. E., Seitzinger, S. P., Carlton, A. G., Turpin, B. J., Klein, G. C., and Marshall, A. G.: Oligomers formed through in-cloud methylglyoxal reactions: chemical composition, properties, and mechanisms investigated by ultra-high resolution FT-ICR mass spectrometry, Atmos. Environ., 42, 1476-1490, 2008.

Angove, D. E., Fookes, C. J. R., Hynes, R. G., Walters, C. K., and Azzi, M.: The characterisation of secondary organic aerosol formed during the photodecomposition of 1,3-butadiene in air containing nitric oxide, Atmos. Environ., 40, 4597-4607, 2006.

Barsanti, K. C. and Pankow, J. F.: Thermodynamics of the formation of atmospheric organic particulate matter by accretion reactions - Part 3: Carboxylic and dicarboxylic acids, Atmos. Environ., 40, 6676-6686, 2006.

Bertman, S. B. and Roberts, J. M.: A PAN analog from isoprene photooxidation, Geophys. Res. Lett., 18(8), 1461-1464, 1991.

Cabada, J. C., Pandis, S. N., and Robinson, A. L.: Sources of atmospheric particulate matter in Pittsburgh, Pennsylvania, J. Air Waste Manag. Assoc., 52, 732-741, 2002.

Calvert, J. G., Atkinson, R., Becker, K. H., Kamens, R. K., Seinfeld, J. H., Wallington, T. J., and Yarwood, G.: The Mechanism of Atmospheric Oxidation of Aromatic Hydrocarbons; Oxford University Press, Inc., New York, USA, 2002.

Chan, C. K., Flagan, R. C., and Seinfeld, J. H.: Water activities of $\mathrm{NH}_{4} \mathrm{NO}_{3} /\left(\mathrm{NH}_{4}\right)_{2} \mathrm{SO}_{4}$ solutions, Atmos. Environ. A-General Topics, 26, 1661-1673, 1992.

Chan, A. W. H., Chan, M. N., Surratt, J. D., Chhabra, P. S., Loza, C. L., Crounse, J. D., Yee, L. D., Flagan, R. C., Wennberg, P. O., and Seinfeld, J. H.: Role of aldehyde chemistry and $\mathrm{NO}_{\mathrm{x}}$ concen- 
trations in secondary organic aerosol formation, Atmos. Chem. Phys., 10, 7169-7188, doi:10.5194/acp-10-7169-2010, 2010.

Claeys, M., Graham, B., Vas, G., Wang, W., Vermeylen, R., Pashynska, V., Cafmeyer, J., Guyon, P., Andreae, M. O., Araxo, P., and Maenhaut, W.: Formation of secondary organic aerosols through photooxidation of isoprene, Science, 303, 1173-1176, 2004a.

Claeys, M., Wang, W., Ion, A. C., Kourtchev, I., Gelencsér, A., and Maenhaut, W.: Formation of secondary organic aerosols from isoprene and its gas-phase oxidation products through reaction with hydrogen peroxide, Atmos. Environ., 38, 4093-4098, 2004b.

Carlton, A. G., Turpin, B. J., Altieri, K. E., Reff, A., Seitzinger, S., Lim, H. J., and Ervens, B.: Atmospheric oxalic acid and SOA production from glyoxal: results of aqueous photooxidation experiments, Atmos. Environ., 41, 7588-7602, 2007.

Carlton, A. G., Wiedinmyer, C., and Kroll, J. H.: A review of secondary organic aerosol (SOA) formation from isoprene, Atmos. Chem. Phys., 9, 4987-5005, doi:10.5194/acp-9-4987-2009, 2009.

Couvidat, F., and Seigneur, C.: Modeling secondary organic aerosol formation from isoprene oxidation under dry and humid conditions, Atmos. Chem. Phys., 11, 893-909, doi:10.5194/acp-11893-2011, 2011.

Dommen, J., Metzger, A., Duplissy, J., Kalberer, M., Alfarra, M. R., Gascho, A., Weingartner, E., Prevot, A. S. H., Verheggen, B., and Baltensperger, U.: Laboratory observation of oligomers in the aerosol from isoprene/ $\mathrm{NO}_{\mathrm{x}}$ photooxidation, Geophys. Res. Lett., 33(13), L13805, doi:10.1029/2006GL026523, 2006.

Edney, E. O., Kleindienst, T. E., Jaoui, M., Lewandowski, M., Offenberg, J. H., Wang, W., and Claeys, M.: Formation of 2-methyl tetrols and 2-methylglyceric acid in secondary organic aerosol from laboratory irradiated isoprene/ $\mathrm{NO}_{\mathrm{X}} / \mathrm{SO}_{2}$ /air mixtures and their detection in ambient $\mathrm{PM}_{2.5}$ samples collected in the eastern United States, Atmos. Environ., 39, 5281-5289, 2005.

Ervens, B. and Volkamer, R.: Glyoxal processing by aerosol multiphase chemistry: towards a kinetic modeling framework of secondary organic aerosol formation in aqueous particles, Atmos. Chem. Phys., 10, 8219-8244, doi:10.5194/acp-10-8219-2010, 2010.

Froyd, K. D., Murphy, S. M., Murphy, D. M., de Gouw, J. A., Eddingsaas, N. C., and Wennberg, P. O.: Contribution of isoprenederived organosulfates to free tropospheric aerosol mass, Proc. Natl. Acad. Sci. USA, 107, 21360-21365, 2010.

Fu, T. M., Jacob, D. J., Wittrock, F., Burrows, J. P., Vrekoussis, M., and Henze, D. K.: Global budgets of atmospheric glyoxal and methylglyoxal, and implications for formation of secondary organic aerosols, J. Geophys. Res., D15303, doi:10.1029/2007JD009505, 2008.

Galloway, M., Chhabra, P. S., Chan, A. W. H., Surratt, J. D., Flagan, R. C., Seinfeld, J. H., and Keutsch, F. N.: Glyoxal uptake on ammonium sulphate seed aerosol: Reaction and reversibility of uptake under dark and irradiated conditions, Atmos. Chem. Phys., 9, 3331-3345, doi:10.5194/acp-9-3331-2009, 2009.

George, I. J. and Abbatt, J. P. D.: Chemical evolution of secondary organic aerosol from $\mathrm{OH}$-initiated heterogeneous oxidation, Atmos. Chem. Phys., 10, 5551-5563, doi:10.5194/acp-10-55512010, 2010.

Gómez-González, Y., Surratt, J. D., Cuyckens, F., Szmigielski, R., Vermeylen, R., Jaoui, M., Lewandowski, M., Offenberg, J. H.,
Kleindienst, T. E., Edney, E. O., Blockhuys, F., Van Alsenoy, C., Maenhaut, W., and Claeys, M.: Characterization of organosulfates from the photooxidation of isoprene and unsaturated fatty acids in ambient aerosol using liquid chromatography/(-) electrospray ionization mass spectrometry, J. Mass Spectrom., 43, 371-382, 2008.

Guenther, A., Hewitt, C. N., Erickson, D., Fall, R., Geron, C., Graedel, T., Harley, P., Klinger, L., Lerdau, M., McKay, W. A., Pierce, T., Scholes, B., Steinbrecher, R., Tallamraju, R., Taylor, J., and Zimmerman, P.: A global model of natural volatile organic compound emissions, J. Geophys. Res., 100, 8873-8891, 1995.

Guenther, A., Karl, T., Harley, P., Wiedinmyer, C., Palmer, P. I., and Geron, C.: Estimates of global terrestrial isoprene emissions using MEGAN (Model of Emissions of Gases and Aerosols from Nature), Atmos. Chem. Phys., 6, 3181-3210, doi:10.5194/acp-63181-2006, 2006.

Hallquist, M., Wenger, J. C., Baltensperger, U., Rudich, Y., Simpson, D., Claeys, M., Dommen, J., Donahue, N. M., George, C., Goldstein, A. H., Hamilton, J. F., Herrmann, H., Hoffmann, T., Iinuma, Y., Jang, M., Jenkin, M. E., Jimenez, J. L., Kiendler-Scharr, A., Maenhaut, W., McFiggans, G., Mentel, Th. F., Monod, A., Prévôt, A. S., Seinfeld, J. H., Surratt, J. D., Szmigielski, R., and Wildt, J.: The formation, properties and impact of secondary organic aerosol: current and emerging issues, Atmos. Chem. Phys., 9, 5155-5236, doi:10.5194/acp-95155-2009, 2009.

Hamilton, J. F., Lewis, A. C., Reynolds, J. C., Carpenter, L. J., and Lubben, A.: Investigating the composition of organic aerosol resulting from cyclohexene ozonlysis: low molecular weight and heterogeneous reaction products, Atmos. Chem. Phys., 6, 49734984, doi:10.5194/acp-6-4973-2006, 2006.

Handley, S. R., Clifford, D., and Donaldson, D. J.: Photochemical loss of nitric acid on organic films: A possible recycling mechanism for $\mathrm{NO}_{\mathrm{x}}$, Environ. Sci. Technol., 41, 3898-3903, 2007.

Henze, D. K. and Seinfeld, J. H.: Global secondary organic aerosol from isoprene oxidation, Geophys. Res. Lett., 33(9), L09812, doi:10.1029/2006GL025976, 2006.

Hoyle, C. R., Berntsen, T., Myhre, G., and Isaksen, I. S. A.: Secondary organic aerosol in the global aerosol chemical transport model Oslo CTM2, Atmos. Chem. Phys., 7, 5675-5694, doi:10.5194/acp-7-5675-2007, 2007.

Hu, D., Tolocka, M., Li, Q., and Kamens, R. M.: A kinetic mechanism for predicting secondary organic aerosol formation from toluene oxidation in the presence of $\mathrm{NO}_{\mathrm{x}}$ and natural sunlight, Atmos. Environ., 41, 6478-6496, 2007.

Jaoui, M., Corse, E. W., Lewandowski, M., Offenberg, J. H., Kleindienst, T. E., and Edney, E. O.: Formation of organic tracers from isoprene SOA under acidic conditions, Atmos. Environ., 44, 1798-1805, 2010.

Kamens, R. M., Zhang, H., Chen, E. H., Zhou, Y., Parikh, H. M., Wilson, R. L., Galloway, K. E., and Rosen, E. P.: Secondary organic aerosol formation from toluene in an atmospheric hydrocarbon mixture: water and particle seed effects, Atmos. Environ., 45, 2324-2334, 2011.

Kleindienst, T. E., Smith, D. F., Li, W., Edney, E. O., Driscoll, D. J., Speer, R. E., Weathers, W. S.: Secondary organic aerosol formation from the oxidation of aromatic hydrocarbons in the presence of dry submicron ammonium sulfate aerosol, Atmos. Environ., 
33, 3669-3681, 2007.

Kleindienst, T. E., Lewandowski, M., Offenberg, J. H., Jaoui, M., and Edney, E. O.: Ozone-isoprene reaction: re-examination of the formation of secondary organic aerosol, Geophys. Res. Lett., 34, L01805, doi:10.1029/2006GL027485, 2007.

Kroll, J. H., Ng, N. L., Murphy, S. M., Flagan, R. C., and Seinfeld, J. H.: Secondary organic aerosol formation from isoprene photooxidation under high-NOx conditions. Geophys. Res. Lett., 32, L18808, doi:10.1029/2005GL023637, 2005.

Kroll, J. H., Ng, N. L., Murphy, S. M., Flagan, R. C., and Seinfeld, J. H.: Secondary organic aerosol formation from isoprene photooxidation, Environ. Sci. Technol., 40, 1869-1877, 2006.

Kroll, J. H., Smith, J. D., Che, D. L., Kessler, S. H., Worsnop, D. R., and Wilson, K. R.: Measurement of fragmentation and functionalization pathways in the heterogeneous oxidation of oxidized organic aerosol, Phys. Chem. Chem. Phys., 11, 8005-8014, doi:10.5194/acp-11-8005-2009, 2009.

Lee, S., Jang, M., and Kamens, R. K.: SOA formation from the photooxidation of $\alpha$-pinene in the presence of freshly emitted diesel soot exhaust, Atmos. Environ., 38, 2597-2605, 2004.

Leungsakul, S., Jeffries, H. E., and Kamens, R. M.: A kinetic mechanism for predicting secondary aerosol formation from the reactions of d-limonene in the presence of oxides of nitrogen and natural sunlight, Atmos. Environ., 39, 7063-7082, 2005.

Lewandowski, M., Jaoui, M., Offenberg, J. H., Kleindienst, T. E., Edney, E. O., Sheesley, R. J., and Schauer, J. J.: Primary and secondary contributions to ambient PM in the midwestern United States, Environ. Sci. Technol., 42, 3303-3309, 2008.

Lim, Y. B., and Ziemann, P. J.: Chemistry of secondary organic aerosol formation from $\mathrm{OH}$ radical-initiated reactions of linear, branched, and cyclic alkanes in the presence of $\mathrm{NO}_{\mathrm{x}}$, Aerosol Sci. Technol., 43, 604-619, 2009.

Müller, L., Reinning, M. C., Warnke, J., and Hoffmann, Th.: Unambiguous identification of esters as oligomers in secondary organic aerosol formed from cyclohexene and cyclohexene $/ \alpha$ pinene ozonolysis, Atmos. Chem. Phys., 8, 1423-1433, doi:10.5194/acp-8-1423-2008, 2008.

Ng, N. L., Kwan, A. J., Surratt, J. D., Chan, A. W. H., Chhabra, P. S., Sorooshian, A., Pye, H. O. T., Crounse, J. D., Wennberg, P. O., Flagan, R. C., and Seinfeld, J. H.: Secondary organic aerosol (SOA) formation from reaction of isoprene with nitrate radicals $\left(\mathrm{NO}_{3}\right)$, Atmos. Chem. Phys., 8, 4117-4140, doi:10.5194/acp-84117-2008, 2008.

Nguyen, T. B., Roach, P. J., Laskin, J., Laskin, A., and Nizkorodov, S. A.: Effect of humidity on the composition and yield of isoprene photooxidation secondary organic aerosol, Atmos. Chem. Phys. Discuss., 11, 9217-9248, doi:10.5194/acpd-119217-2011, 2011.

Nozière, B., Ekström, S., Alsberg, T., and Holmstrom, S.: Radical-initiated formation of organosulfates and surfactants in atmospheric aerosols, Geophys. Res. Lett., 37, L05806, doi:10.1029/2009GL041683, 2010.

Offenberg, J. H., Lewandowski, M., Edney, E. O., Kleindienst, T. E., and Jaoui, M.: Influence of aerosol acidity on the formation of secondary organic aerosol from biogenic precursor hydrocarbons, Environ. Sci. Technol., 43, 7742-7747, 2009.

Orlando, J. J.: Recent advances in the determination of the oxidation mechanisms of isoprene and its by-products, International Conference of Atmospheric Chemistry Mehcanism, 10 Decem- ber 2010, 2010.

Orlando, J. J., Tyndall, G. S., Bertman, S. B., Chen, W., and Burkholder, J. B.: Rate coefficient for the reaction of $\mathrm{OH}$ with $\mathrm{CH}_{2}=\mathrm{C}\left(\mathrm{CH}_{3}\right) \mathrm{C}(\mathrm{O}) \mathrm{OONO}_{2}(\mathrm{MPAN})$, Atmos. Environ., 36, 1895-1900, 2002.

Paulot, F., Crounse, J. D., Kjaergaard, H. G., Kürten, A., St. Clair, J. M., Seinfeld, J. H., and Wennberg, P. O.: Unexpected epoxide formation in the gas-phase photooxidation of isoprene, Science, 325, 730-733, 2009.

Paulson, S. E., Flagan, R. C., and Seinfeld, J. H.: Atmospheric photooxidation of isoprene Part I: The hydroxyl radical and ground state atomic oxygen reactions, Int. J. Chem. Kinet., 24, 79-101, 1992.

Paulson, S. E., Flagan, R. C., Seinfeld, J. H.: Atmospheric photooxidation of isoprene Part II: The ozone-isoprene reaction, Int. J. Chem. Kinet., 24, 103-125, 1992.

Perri, M. J., Lim, Y. B., Seitzinger, S. P., and Turpin, B. J.: Organosulfates from glycolaldehyde in aqueous aerosols and clouds: Laboratory studies, Atmos. Environ., 44, 2658-2664, 2010.

Sato, K.: Detection of nitrooxypolyols in secondary organic aerosol formation from the photooxidation of conjugated dienes under high- $\mathrm{NO}_{\mathrm{x}}$ conditions, Atmos. Environ., 42, 6851-6861, 2008.

Sato, K., Nakao, S., Clark, C. H., Qi, L., and Cocker III, D. R.: Secondary organic aerosol formation from the photooxidation of isoprene, 1,3-butadiene, and 2,3-dimethyl-1,3-butadiene under high $\mathrm{NO}_{\mathrm{x}}$ conditions, Atmos. Chem. Phys. Discuss., 11, 4313-4354, doi:10.5194/acpd-11-4313-2011, 2011.

Surratt, J. D., Murphy, S. M., Kroll, J. H., Ng, N. L., Hildebrabdt, L., Sorooshian, A., Szmigielski, R., Vermeylen, R., Maenhaut, W., Claeys, M., Flagan, R. C., and Seinfeld, J. H.: Chemical composition of secondary organic aerosol formed from the photooxidation of isoprene. J. Phys. Chem. A., 110, 9665-9690, 2006.

Surratt, J. D., Kroll, J. H., Kleindienst, T. E., Claeys, M., Sorooshian, A., Ng, N. L., Offenberg, J. H., Lewandowski, M. Jaoui, M., Flagan, R. C., and Seinfeld, J. H.: Evidence for organosulfates in secondary organic aerosol, Environ. Sci. Technol., 41, 517-527, 2007a.

Surratt, J. D., Lewandowski, M., Offenberg, J. H., Jaoui, M., Kleindienst, T. E., Edney, E. O., and Seinfeld, J. H.: Effect of acidity on secondary organic aerosol formation from isoprene, Environ. Sci. Technol., 41, 5363-5369, 2007b.

Surratt, J. D., Gómez-González, Y., Chan, A. W. H., Vermeylen, R., Shahgholi, M., Kleindienst, T. E., Edney, E. O., Offenberg, J. H., Lewandowski, M., Jaoui, M., Maenhaut, W., Claeys, M., Flagan, R. C., and Seinfeld, J. H.: Organosulfate formation in biogenic secondary organic aerosol, J. Phys. Chem. A., 112, 8345-8378, 2008.

Surratt, J. D., Chan, A. W. H., Eddingsaas, N. C., Chan, M., Loza, C. L., Kwan, A. J., Hersey, S. P., Flagan, R. C., Wennberg, P. O., and Seinfeld, J. H.: Reactive intermediates revealed in secondary organic aerosol formation from isoprene, Proc. Natl. Acad. Sci. USA, 107, 6640-6645, 2010.

Szmigielski, R., Surratt, J. D., Vermeylen, R., Szmigielska, K., Kroll, J. H., Ng, N. L., Murphy, S. M., Sorooshian, A., Seinfeld, J. H., and Claeys, M.: Characterization of 2-methylglyceric acid oligomers in secondary organic aerosol formation from the photooxidation of isoprene using trimethylsilylation and gas chro- 
matography/ion trap mass spectrometry, J. Mass Spectrom., 42, 101-116, 2007.

Szmigielski, R., Vermeylen, R., Dommen, J., Metzger, A., Maenhaut, W., Baltensperger, U., and Claeys, M.: The acid effect in the formation of 2-methyltetrols from the photooxidation of isoprene in the presence of $\mathrm{NO}_{\mathrm{x}}$, Atmos. Res., 98, 183-189, 2010.

Turpin, B. J. and Huntzicker, J. J.: Identification of secondary organic aerosol episodes and quantitation of primary and secondary organic aerosol concentration during SCAQS, Atmos. Environ., 29, 3527-3544, 1995.

Turpin, B. J. and Lim, H. J.: Species contributions to PM $_{2.5}$ mass concentrations: Revisiting common assumptions for estimating organic mass, Aerosol Sci. Technol., 35, 602-610, 2001.

Volkamer, R., Ziemann, P. J., and Molina, M. J.: Secondary Organic Aerosol Formation from Acetylene $\left(\mathrm{C}_{2} \mathrm{H}_{2}\right)$ : seed effect on SOA yields due to organic photochemistry in the aerosol aqueous phase, Atmos. Chem. Phys., 9, 1907-1928, doi:10.5194/acp9-1907-2009, 2009.
Xu, J., Imre, D., McGraw, R., and Tang, I.: Ammonium sulfate: Equilibrium and metastability phase diagrams from 40 to $-50{ }^{\circ} \mathrm{C}$, J. Phys. Chem. B, 102, 7462-7469, 1998.

Zhou, Y., Zhang, H., Parikh, H. M., Chen, E. H., Rattanavaraha, W., Rosen, E. P., Wang, W., and Kamens, R. M.: Secondary organic aerosol formation from xylenes and mixtures of toluene and xylenes in an atmospheric urban hydrocarbon mixture: Water and particle seed effects (II), Atmos. Environ., 45, 38823890, 2011. 